Jasna D. Bićanić

UDK 371.3:811.163.42

Univerzitet u Zagrebu

Stručni rad

10.19090/mv.2016.7.181-198

Filozofski fakultet, Zagrebu - Poslijediplomski doktorski studij glotodidaktike

Zagreb

Univerzitet u Rijeci

Filozofski fakultet, Rijeka (vanjski suradnik)

Rijeka

jasna.bicanic@uniri.hr

\title{
NEKNJIŽEVNI TEKSTOVI U POUČAVANJU STRATEGIJE SAŽIMANJA
}

\begin{abstract}
APSTRAKT
Uključivanje neknjiževnih tekstova u nastavu hrvatskog jezika, jedinoga nastavnog predmeta odgovornog za sustavno poučavanje čitanju, doprinosi ostvarivanju njegova cilja - ovladavanju sadržajima svih nastavnih predmeta. Tri su temeljne odrednice ovog rada: razumijevanje pri čitanju, strategije učenja i čitanja, te neknjiževni tekstovi. U vezi s čitanjem neknjiževnih tekstova ističe se povezanost s razumijevanjem pri čitanju te poučavanjem i upotrebom strategija čitanja i učenja. Strategije čitanja valja poučavati u svim nastavnim područjima hrvatskog jezika na predlošcima književnih i neknjiževnih tekstova, a ovaj je rad pažnju usmjerio neknjiževnim tekstovima, koji još uvijek nisu u odgovarajućoj mjeri pronašli svoje mjesto u svekolikoj nastavnoj praksi. Metodičkim se modelom nastavnog sata prikazuje mogućnost uključivanja neknjiževnog teksta kao nastavnog sadržaja i nastavnog izvora u drugi odgojnoobrazovni ciklus metodom postupnog prenošenja odgovornosti i smjernice učiteljima u odabiru didaktički nepriređenih neknjiževnih tekstova, s ciljem poučavanja i uvježbavanja jedne od ključnih strategija učenja i čitanja - strategije sažimanja.
\end{abstract}

Ključne riječi: neknjiževni tekst, strategije čitanja, sažimanje, Hrvatski jezik, model postupnog prenošenja odgovornosti. 


\title{
NON-LITERARY TEXTS IN TEACHING THE STRATEGY OF SUMMARIZING
}

\begin{abstract}
Inclusion of non-literary texts in teaching the Croatian language, the only subject responsible for the systematic teaching of reading, contributes to the achievement of its objective - mastering the content of all school subjects. There are three basic guidelines in this paper: reading comprehension, learning and reading strategies, and non-literary text. Regarding the reading of non-literary texts, the paper emphasizes the correlation with understanding in reading and teaching and the use of reading and learning strategies. Reading strategies should be taught in all educational areas of the Croatian language in both literary and non-literary texts, and this paper focuses on non-literary texts, which have not yet found an appropriate place in the overall teaching practice. Methodological model of the lesson shows the possibility of including non-literary texts as a teaching content and teaching resource in the second educational cycle using Gradual Release of Responsibility Model and guidelines for teachers in choosing didactically unprepared non-literary texts, with the aim of teaching and training one of the key strategies of learning and reading summarizing strategy.
\end{abstract}

Key words: non-literary text, reading strategies, summarizing, Croatian language, Gradual Release of Responsibility Model.

\section{UVOD}

Neknjiževni tekstovi neiskorišteni su potencijal nastavne prakse Hrvatskog jezika, posebice uzmemo li u obzir načela cjelokupnosti jezične i komunikacijske prakse, teksta, općeobrazovnosti i odgojnosti, te samo određenje cilja nastave Hrvatskog jezika prema Nastavnom planu i programu. U radu će se progovoriti o određenju pojma neknjiževni tekst, smjernicama učiteljima za odabir didaktički nepriređenih neknjiževnih tekstova te, primjenom modela postupnog prenošenja odgovornosti, prikazati mogućnost oblikovanja i izvedbe nastavnog sata uvježbavanja jedne od temeljnih strategija učenja i čitanja - strategije sažimanja. Uzimajući u obzir povezanost neknjiževnih tekstova s razumijevanjem pri čitanju i poučavanjem strategija čitanja, smatramo iznimno važnim poučavati strategije čitanja, ne samo na tekstovima književnoumjetničkog stila, već i na tekstovima svih drugih funkcionalnih stilova, što se, pretpostavljamo, preslikava 
i na upamćivanje informacija iz pročitanih tekstova i svekoliko učenje u svim drugim nastavnim predmetima i uspješnost u učenju.

\section{NEKNJIŽEVNI TEKST U NASTAVI HRVATSKOG JEZIKA - POTENCIJAL ODGOJNO-OBRAZOVNOG PROCESA}

Cilj nastave Hrvatskog jezika, prema Nastavnom planu i programu za osnovnu školu iz 2006., jest osposobiti učenike za jezičnu komunikaciju koja im omogućuje ovladavanje sadržajima svih nastavnih predmeta i uključivanje u cjeloživotno učenje (Nastavni plan i program za osnovnu školu 2006: 25). Jezična se komunikacija ili sporazumijevanje ostvaruje primanjem i odašiljanjem poruka, primanje jezičnim djelatnostima slušanja i čitanja s ciljem razumijevanja jezične poruke, a odašiljanje jezičnim djelatnostima govorenja i pisanja, što pretpostavlja jezičnu proizvodnju.

Izdvojit ćemo još jednu odrednicu Nastavnog plana i programa za osnovnu školu, ključnu za uključivanje i pridavanje važnosti neknjiževnim tekstovima u nastavi Hrvatskoga jezika, jer je učenik u svojoj svakodnevici okružen tekstovima svih funkcionalnih stilova, a škola mu treba dati oruđe za njihovo čitanje i razumijevanje (Nemeth-Jajić 2013: 105).

„Ostvarivanje svrhe i zadaće nastave Hrvatskoga jezika pridonosi razvoju jezično-komunikacijskih sposobnosti pri govornoj i pisanoj uporabi jezika u svim funkcionalnim stilovima.“ (Nastavni plan i program za osnovnu školu 2006: 25)

Nacionalni okvirni kurikulum za predškolski odgoj i obrazovanje, te opće obavezno i srednjoškolsko obrazovanje (2010: 31) kao odgojno-obrazovni cilj jezično-komunikacijskog područja ističe učeničko stjecanje potrebnih razina slušanja, govorenja, čitanja i pisanja ključnih za učenje, rad i život, tj. razvijanje sposobnosti komunikacije u različitim situacijama, a potom se za svaku jezičnu djelatnost razrađuju učenička postignuća. Izdvajamo ona postignuća jezičnih djelatnosti slušanja i čitanja u 2. i 3. odgojno-obrazovnom ciklusu ${ }^{1}$

1 Nacionalni okvirni kurikulum (2010: 19) određuje četiri odgojno-obrazovna ciklusa za stjecanje temeljnih kompetencija. Prvi ciklus čine I., II., III. i IV. razred osnovne škole, drugi ciklus čine V. i VI. razred osnovne škole, treći ciklus čine VII. i VIII. razred osnovne škole, a četvrti ciklus obuhvaća ili sve razrede srednje škole za gimnazije ili I. i II. razred srednjih strukovnih i umjetničkih škola. U ovom radu usmjereni smo višim razredima osnovne škole (od 5. do 8. razreda), što obuhvaća II. i III. odgojno-obrazovni ciklus, te će u skladu s tim biti prikazana obrazovna postignuća jezičnokomunikacijskog područja za Hrvatski jezik. 
koja eksplicitno izdvajaju neknjiževne tekstove kao važnu odrednicu nastave predmeta Hrvatski jezik.

„Jezična djelatnost: slušanje (II. odgojno-obrazovni ciklus)

Učenici će:

$\checkmark$ uočiti i razlikovati ključne riječi, ideje i jezična obilježja jednostavnih ${ }^{2}$ neknjiževnih i književnoumjetničkih tekstova, zadanih i samostalno odabranih;

$\checkmark$ tijekom slušanja procijeniti u različite svrhe sadržajne, jezične i teorijske podatke u jednostavnim neknjiževnim i književnoumjetničkim tekstovima, zadanima i samostalno odabranima." (NOK 2010: 36)

„Jezična djelatnost: čitanje (II. odgojno-obrazovni ciklus)

Učenici će:

$\checkmark$ učiti, razlikovati i opisati ključne riječi, ideje i jezična obilježja jednostavnih neknjiževnih i književnoumjetničkih tekstova, zadanih i samostalno odabranih;

$\checkmark$ tijekom čitanja procijeniti u različite svrhe sadržajne i jezične podatke i teorijske podatke o tekstu jednostavnijih neknjiževnih i književnoumjetničkih tekstova, zadanih i samostalno odabranih;

$\checkmark$ protumačiti i samostalno procijeniti nepoznate jednostavnije neknjiževne i književnoumjetničke tekstove, zadane i samostalno odabrane." (NOK 2010: 40)

Nacionalni okvirni kurikulum (2010) ističe tri važne odrednice ovoga rada, razumijevanje pri čitanju, strategije čitanja i učenja i neknjiževne tekstove jer se kao obrazovno postignuće izdvaja da će učenici razlikovati, odabrati i primijeniti veći broj kognitivnih, metakognitivnih i društveno-afektivnih strategija prije čitanja i tijekom čitanja jednostavnih/složenih književnih i neknjiževnih tekstova, te razumjeti različite vrste tekstova (NOK 2010: 46). Neknjiževne bi tekstove trebalo više uključivati u nastavu jezičnog izražavanja (ali i nastavu predmetnog područja hrvatski jezik), uvažavajući načela teksta, cjelokupnosti jezične i komunikacijske prakse, sadržajne, tekstovne i stilske raznovrsnosti, ali i zanimljivosti, općeobrazovnosti, odgojnosti, te stvaralaštva. Unatoč tome što je obrazovnom politikom i zakonskom regulativom prepoznata važnost neknjiževnih tekstova za nastavu materinskog jezika i ostvarivanje cjelokupnosti jezične i komunikacijske prakse učenika, a to potvrđujemo ranije navedenim

2 Za III. su odgojno-obrazovni ciklus postignuća usmjerena složenijim neknjiževnim i književnoumjetničkim tekstovima (NOK 2010: 36). 
određenjem cilja nastave Hrvatskog jezika i obrazovnih postignuća naših učenika, nastavna se praksa i dalje uglavnom temelji na tekstovima književnoumjetničkog stila tako što se jezične pojave i različiti oblici jezičnog izražavanja uočavaju i poučavaju na lingvometodičkim predlošcima književnoumjetničkog stila, a nastavi se književnosti i školske lektire ${ }^{3}$ i dalje posvećuje mnogo pozornosti, dok je za cjelokupnost jezične i komunikacijske prakse prijeko potrebno više uključiti i tekstove svih ostalih funkcionalnih stilova. U nastavku ćemo prikazati zašto je važno uključivanje neknjiževnih tekstova u ostvarivanje ciljeva i zadaća nastave Hrvatskog jezika.

\subsection{Neknjiževni tekst - pojmovno određenje}

Samo određenje i razlikovanje književnog i neknjiževnog teksta uočavamo u zapisu M. Solara. Ako tekstom (lat. textum - tkanje, tkanina, sveza riječi) nazivamo ono što je na nekom jeziku zapisano ili utvrđeno na neki drugi način, književno djelo treba primarno shvatiti kao bilo koji tekst, a od neknjiževnog ga teksta razlikuje način čitanja (razumijevanje rečenica iz stvarnog konteksta ili cjeline vlastitog iskustva) i osobine samog teksta koje upozoravaju da se književno djelo služi jezikom na osobit način (Solar 1996: 13-14). Z. Lešić razlikuje književne tekstove koji imaju neke svoje bitne osobine kojima ostvaruju posebnost u odnosu na druge stvaralačke djelatnosti ljudske jedinke i kojima ih prepoznajemo kao književne tekstove. Te tekstove, jednom prepoznate kao književne, stavljamo u opreku prema drugim jezičnim iskazima, neknjiževnim tekstovima - znanstvenim, filozofskim, povijesnim i publicističkim. U razlikovanju umjetničkog i običnog teksta, R. Katičić (u Udier, 2011) izdvaja doživljaj i obavijesnost. Određeni nam iskaz u običnom tekstu pruža informacije o stvarnom svijetu i ima stvarni kontekst, a u književnom tekstu značenje dobiva iz ukupnosti čitateljeva životnog iskustva i poprima emocionalno značenje. Obavijesnost književnog teksta, prema R. Katičiću, manja je od bilo koje izvanknjiževne obavijesti jer ona ima samo svoj unutrašnji kontekst, neovisan od stvarnog svijeta.

Književnim tekstovima, odnosno književnoumjetničkom riječju, u nastavi Hrvatskoga jezika potičemo i razvijamo u učenika osjećaj za ljepotu literarnog stila, ljubav prema književnoumjetničkoj riječi, te razvijanje i stjecanje literarnog iskustva. Neknjiževni tekstovi u nastavi Hrvatskog jezika obuhvaćaju tekstove znanstvenog, novinarskog, administrativnog, razgovornog stila, ali i tekstove

3 Vidi Nemeth-Jajić (2013: 105). 
sekundarnih funkcionalnih stilova: esejističkog, scenarističkog, reklamnog, stripovnog i retoričkog, te epistolarnog i sakralnog stila 4 .

K. Visinko navodi neke vrste neknjiževnih tekstova koje treba obuhvatiti čitanje djetetu ili učeniku. To su: zanimljive vijesti i članci iz novina i časopisa, ulomci iz enciklopedijskih ili leksikonskih natuknica o djeci zanimljivim sadržajima, natpisi, kazališni plakati i reklame (Visinko 2014: 13), odnosno tekstovi znanstvenopopularnog, znanstvenog, udžbeničkog, novinarskog, epistolarnog i sakralnog stila (Visinko 2003: 23-24). Uz naziv neknjiževni tekst u literaturi javljaju se termini u opoziciji, ekspozitorni i narativni tekst ${ }^{5}$, što zahtijeva detaljniju razradu i analizu nekoga budućeg rada.

Neknjiževni se tekstovi u nastavu Hrvatskog jezika uključuju na dva načina: kao nastavni sadržaj i kao nastavni izvor (Nemeth-Jajić 2013: 108-109). J. Nemeth-Jajić (2013: 108-110) naglašava kako se neknjiževni tekst u 2. i 3. obrazovnom ciklusu kao nastavni sadržaj (usmjerenost funkcionalnostilističkim značajkama pojedine tekstovne vrste) pojavljuje u nastavnim područjima jezičnog izražavanja i medijske kulture, dok se kao nastavni izvor (usmjerenost obavijesnom ustrojstvu teksta) može pojaviti u svim nastavnim područjima.

$\mathrm{U}$ vezi s čitanjem neknjiževnih tekstova ističe se povezanost $\mathrm{s}$ razumijevanjem pri čitanju, te poučavanjem i upotrebom strategija čitanja i učenja za koje je zadužena nastava materinskoga jezika jer čitanju poučavamo učenike samo u nastavi Hrvatskog jezika, a ono se podrazumijeva u svim ostalim nastavnim predmetima. Ove tvrdnje potkrijepljene su rezultatima istraživanja S. Kolić-Vehovec, S. Pejčak i B. Rončević (2009: 237) među slovenskim i hrvatskim adolescentima kojem je cilj bio istražiti razlikuju li se učenici tih dviju zemalja u razumijevanju pri čitanju te (meta)kognitivnim i motivacijskim čimbenicima. Istraživanje je pokazalo kako slovenski učenici pokazuju bolje razumijevanje ekspozitornih tekstova, a autorice kao mogući uzrok takvih rezultata ističu ciljane akcije za unapređenje pismenosti učenika osnovne škole

4 Funkcionalni stilovi razvijaju se, nadopunjavaju, revidiraju i unapređuju u skladu s razvojem društva, a u ovome se radu opredjeljujemo za podjelu M. Katnić-Bakaršić (1999: 23).

5 Kolić-Vehovec, S., Pejčak, S., Rončević Zubković, B. (2009); Bajšanski, I. (2011); ČudinaObradović (2014).

Čudina-Obradović (2014: 195-196) razlikuje priču (narativni tekst) i izlaganje (ekspozitorni tekst). Priča (narativni tekst) ima uobičajenu strukturu, početak, sredinu i kraj, linearni oblik i odvija se u vremenskom slijedu. Elementi strukture narativnog teksta su: likovi, mjesto, problem i rješenje problema. Izlaganje (ekspozitorni tekst) je ona vrsta teksta s kojom se učenici najčešće sureću u školi jer je to tekst udžbenika i svih ostalih pisanih izvora informacija. U ekspozitornom se tekstu učenici susreću s novim sadržajima i nepoznatim pojmovima. Dva su najčešća oblika ekspozitornih tekstova u osnovnoj školi: opis i redoslijed. 
u Sloveniji poduzete u okviru školske reforme nakon 1998. godine kad je u poučavanju čitanja značajno povećan broj ekspozitornih tekstova (izjednačen broj ekspozitornih i narativnih tekstova), te stavljen veći naglasak na procesna znanja, odnosno na poučavanje različitih strategija čitanja.

U ovom ćemo radu metodičkim modelom nastavnog sata prikazati uključivanje neknjiževnog teksta kao nastavnog sadržaja (funkcionalnostilističke značajke teksta) i nastavnog izvora (usmjerenost obavijesnom ustrojstvu teksta) u 5. razredu osnovne škole i smjernice učiteljima u odabiru neknjiževnih tekstova, a s ciljem poučavanja jedne od ključnih strategija učenja i čitanja - strategije sažimanja.

\section{3 ČITANJE I RAZUMIJEVANJE PRI ČITANJU}

Svjesni smo izloženosti naših učenika pisanim materijalima kao izvorima učenja i koliko je čitanje kao jezična djelatnost važno za uspjeh u cjelokupnom odgojno-obrazovnom procesu. Daneman (1996. u Kolić-Vehovec 2013: 23) čitanje definira kao temeljnu generičku intelektualnu vještinu nužnu za uspješno djelovanje u suvremenom svijetu. Čitanje smatra posebno važnim za učenje iz teksta jer ono u velikoj mjeri određuje uspješnost tijekom školovanja (oko $1 / 3$ varijance školskog uspjeha određeno je uspješnošću razumijevanja pri čitanju). Preduvjet usmjeravanja kognitivnih procesa razumijevanju teksta jest ovladavanje prepoznavanjem znakova i riječi, odnosno automatizacija tog procesa, koji optimalnu razinu dostiže do 8. ili 9. godine života (Kolić-Vehovec 2013: 23).

Razumijevanje pri čitanju i uspješnost u učenju pozitivno su povezani sa strategijama čitanja (Kolić-Vehovec 2013: 27), te je, prema K. Visinko (2014: 94), razumijevanje uvjet da bismo učili, istraživali, analizirali, tumačili, stvarali, pisali. Ne trebamo podrazumijevati učeničko razumijevanje čitanog ili slušanog teksta, već ono mora biti dio svakodnevne nastavne prakse uvježbavanja na različitim vrstama tekstova. Poučavanje razumijevanja pomaže prosječnim i ispodprosječnim čitateljima, a iznadprosječnim je čitateljima korisno kao poticaj za uporabu strategija razumijevanja (Čudina-Obradović 2014: 205-206). Dobre čitatelje obilježava upotrebljavanje niza različitih strategija čitanja, upotrebljavanje različitih strategija za različite zadatke, te vrednovanje i nadgledanje učinkovitosti upotrebljene strategije. Takvog čitatelja Pressley i Afflerbach (Kolić-Vehovec 2013: 27) nazivaju konstruktivno reaktivnim jer pažljivo raspoređuje kognitivne resurse tijekom čitanja. Za razliku od njih, loši čitatelji koriste mali broj strategija $\mathrm{i}$ često koriste iste strategije $\mathrm{u}$ različitim 
situacijama (Rončević Zubković 2013: 35). U vezi s tim, prikazat ćemo kategorizaciju strategija čitanja.

\subsection{Kategorizacija strategija čitanja}

Paris, Wasik, Turner (1996. u Kolić-Vehovec 2013: 27) kategoriziraju strategije prema vremenskom slijedu njihova pojavljivanja u odnosu na tekst koji se čita. Razlikuju strategije koje se javljaju:

a) prije čitanja: pregledavanje slika, teksta, naslova i podnaslova;

b) tijekom čitanja: identifikacija glavne ideje, stvaranje zaključaka i pregledavanje teksta $\mathrm{i}$

c) nakon čitanja: razmišljanje o pročitanome, zauzimanje osobnog stava, sažimanje.

Neke se strategije, poput pregledavanja teksta, mogu pojavljivati u svim fazama čitanja.

K. Visinko (2014: 94-95) izdvaja najučinkovitije strategije prema izvješću Mreže Eurydice. To su: nadgledanje (provjera) vlastitog razumijevanja, suradničko učenje, stvaranje vizualnih prezentacija, odgovaranje na pitanje, postavljanje pitanja, ustroj teksta, sažimanje teksta i selektivna usmjerenost na tekst. Autorica navodi i izvođenje zaključaka ili tumačenje, povezivanje različitih dijelova teksta i primjenu prethodnog znanja. Izdvaja još tri strategije na koje upućuje praksa, a to su: pregledavanje teksta, predviđanje o razvoju sadržaja teksta, te prepoznavanje vlastitih ideja.

\subsection{Poučavanje strategija čitanja}

Zbog važnosti strategija za razumijevanje pri čitanju, pamćenje informacija iz pročitanih tekstova i učenje, ističe se i potreba njihova poučavanja, uvježbavanja i osvješćivanja njihove upotrebe, te nadgledanja i vrednovanja napretka. U tom procesu, nezaobilazna je uloga učitelja koji će poučavanjem strategija pomoći učenicima u učenju i razumijevanju tekstova koje čitaju. U metodičkom modelu nastavnog sata koji će biti prikazan, primijenit ćemo model postupnog prenošenja odgovornosti ${ }^{6} \mathrm{~S}$. L. Horner i C. S. Shweryja (Rončević

6 Kolić-Vehovec ističe ovu metodu najboljom za poučavanje strategijama.

Čudina-Obradović (2014: 228) ističe poučavanje sažimanju u okviru recipročnog poučavanja, a 
Zubković 2013: 34-36). Taj se model sastoji od triju metoda poučavanja strategijama:

\section{a) modeliranje}

U ovoj fazi učitelj izvodi zadatak, a učenici promatraju i stvaraju predodžbe o procesima potrebnim za izvođenje zadatka. Učitelj se pritom služi metodom razmišljanja naglas, verbalizirajući svoja razmišljanja dok izabire, koristi i nadgleda upotrebu strategija. Učenici tako dobivaju uvid u učiteljev način razmišljanja, objašnjavajući kada, zašto i na koji način koristi neku od strategija čitanja, kako odabire ciljeve, na koji način procjenjuje vlastiti napredak te što razmišlja o vlastitim sposobnostima i motivaciji. Modeliranje, također, može uključivati i same učenike kao modele, tako da oni mogu međusobno, u malim grupama, komentirati načine pristupa pojedinom tekstu, te učinkovite $\mathrm{i}$ manje učinkovite strategije, pri čemu oni učenici koji su manje uspješni mogu učiti od onih boljih (Rončević Zubković, 2013: 36).

\section{b) promatranje izvođenja zadatka}

Nastavlja se na fazu modeliranja i obuhvaća učiteljevo promatranje izvođenja zadatka samih učenika. Učitelj daje povratnu informaciju, sugestije, podupire učenike i po potrebi ponovno modelira upotrebu strategija. Mogu se koristiti razni oblici vanjske podrške kako bi učenik uspješno izvršio zadatak, ali ih postupno treba uklanjati.

\section{c) samostalno uvježbavanje}

Učenici dobivaju zadatak za samostalno uvježbavanje strategija.

Ovaj model primjenjiv je na poučavanje učenika svim strategijama čitanja, a posebno izdvajamo jednu od najučinkovitijih strategija učenja i poučavanja strategiju sažimanja.

temelji se na postupcima: 1 . objašnjavanje strategije; 2 . zajedničko čitanje naglas i jasni primjeri strategije; 3. čitanje novoga teksta i samostalan rad učenika na novome tekstu (rad u malim skupinama); 4. dijalog između izabranog vođe skupine i skupine učenika; 5. vođa sažimlje sadržaj, diskutira i razjašnjava nejasnoće, formulira predviđanja o sljedećem sadržaju; 6. svaki je član skupine vođa u jednom čitanju. Prikazani se metodički model nastavnog sata (u nastavku) može prirediti i u okviru recipročnog poučavanja. 


\section{SAŽIMANJE - STRATEGIJA UČENJA I ČITANJA}

Istraživanje čitanja potvrdilo je uspješnost u poučavanju učenika četvrtih razreda osnovne škole (1. odgojno-obrazovni ciklus) sažimanju književnih i neknjiževnih tekstova (Visinko 2010: 160), te učenika 5. razreda u poučavanju sažimanja narativnih tekstova (Kolić-Vehovec, Muranović, 2004. u ČudinaObradović 2014: 228). Sažimanje je među najučinkovitijim strategijama učenja i čitanja, a temelji se na prepoznavanju biti teksta, procjeni važnosti informacija, ispuštanju nevažnih informacija i organiziranju i sažimanju važnih informacija (Kolić-Vehovec 2013: 26). U oblikovanju sažetka, najtežeg oblika jezičnog izražavanja, potrebno je poticati oblikovanje vlastitih formulacija. Tako oblikovan sažetak u potpunosti može zamijeniti izvorni tekst jer sadržava temeljne ideje i ključne pojmove.

Međutim, prije daljnje razrade, valja objasniti razliku između triju sličnih, ali ipak različitih pojmova - parafraziranja, prepričavanja i sažimanja kako tumači E. Kissner (2006: 6-7). Autorica parafraziranje definira kao iskazivanje ideja drugim, vlastitim riječima. Prepričavanje je usmeno iskazivanje upamćenog iz slušanog ili pročitanog teksta. Ova su dva procesa blisko povezana sa sažimanjem i prethode mu, ali se razlikuju u procesu, formi i proizvodu. Obilježje sažimanja jest skraćivanje originalnog teksta koje obuhvaća glavne autorove ideje, uključuje važne informacije koje podupiru te ideje, te reflektira strukturu i redoslijed originalnog teksta.

Uvidom u Nastavni plan i program za osnovnu školu za Hrvatski jezik od 1. do 8. razreda, prepričavanje je zastupljeno u sljedećim nastavnim temama: stvaralačko prepričavanje (5. razred); stvaralačko prepričavanje s promjenom gledišta (6. razred); sažeto prepričavanje (6. razred). Sažimanje se, za razliku od prepričavanja, kao nastavna tema obrađuje samo u 4. razredu (sažimanje pripovjednih tekstova) te djelomično $u$ temi sažeto prepričavanje (6. razred). Uvježbavanje se sažimanja u nastavnoj praksi dijelom ostvaruje u određivanju kompozicijskih dijelova pročitanog i slušanog književnoumjetničkoga proznog teksta (lektira ili ulomak) jer određivanje kompozicijskih dijelova sadrži neka temeljna obilježja sažimanja (kraćenje u odnosu na originalni tekst, obuhvaća glavne autorove ideje te reflektira strukturu i redoslijed originalnog teksta). Određivanje kompozicijskih dijelova poučava se i uvježbava tijekom svih razreda osnovne škole i dijelom je gotovo svih nastavnih sati interpretacije proznog ili dramskog teksta. Kompozicijske dijelove možemo uvježbavati određivanjem naslova dijelu teksta jednom riječju, sintagmom, rečenicom, pitanjem ili pisanjem natuknice. Možemo izdvajati i ključne riječi (Visinko 2010: 160). U nastavi su jezičnog izražavanja učitelji usmjereni uvježbavanju prepričavanja, i to uglavnom 
na književnoumjetničkim predlošcima, a bilo bi vrijedno uvježbavati i strategiju sažimanja uvijek kad za to imamo prigodu. Vježbe sažimanja (ali i prepričavanja) u nastavi hrvatskog jezika, kad lingvometodički predložak jest ili književni ili neknjiževni tekst, izostaju zbog ekonomičnog korištenja vremena predviđenog za obradbu određenoga gramatičkog ili pravopisnog nastavnog sadržaja propisanog nastavnim programom. K. Visinko (2014: 109-110) izdvaja vježbe sažimanja u kojima učenici na razini riječi, sintagme i rečenice uvježbavaju sažimati pojedine dijelove pročitanog teksta i pisanje što više naslova za tekst koji su pročitali.

Vježbe sažimanja mogu se i trebaju uključivati u uvodne, središnje i završne dijelove sati svih nastavnih područja hrvatskog jezika, uvijek kad smo to u mogućnosti napraviti. Sažimanje treba uvježbavati kad je nastavni izvor i književni i neknjiževni tekst jer valja imati na umu da je za uspješno samostalno korištenje sažimanja potrebno višekratno modeliranje i uvježbavanje na različitim tekstovima. Kako poučavati sažimanje po modelu postupnog prenošenja odgovornosti, prikazat ćemo na neknjiževnom tekstu. Iako ćemo vježbe sažimanja najčešće provoditi u pojedinim dijelovima obradbe, uvježbavanja ili usustavljivanja nastavnog sadržaja svih nastavnih područja prema programu, a ne kao zasebne nastavne jedinice, ponekad, kad za to imamo prigodu, posvetit ćemo cijeli nastavni sat uvježbavanju strategije sažimanja, a sve se navedeno odnosi i može primijeniti i na sve druge strategije čitanja.

\subsection{Osobitosti neknjiževnog teksta za uvježbavanje strategije sažimanja}

Prilikom odabira neknjiževnih tekstova kao nastavnog izvora, koji ćemo upotrebljavati za uvježbavanje strategije sažimanja, valja se voditi didaktičkim, metodičkim i psihološkim smjernicama koje smanjuju mogućnost narušavanja razumijevanja pri čitanju i smanjivanju motivacije za čitanje. Često će učitelj sam biti istraživač i pronalaziti prigodne neknjiževne tekstove u tiskovinama ili se služiti internetskim izvorima. Pritom se valja voditi dolje navedenim smjernicama:

a) Primjerenost tekstova učeničkom rječniku (bogatstvo rječnika uvelike određuje razumijevanje, a nepoznavanje većeg broja riječi vodi izbjegavanju čitanja) ${ }^{7}$

b) Povezanosts prethodnim znanjem oodređenom području (za razumijevanje

7 Bast i Reitsma, 1998; Cain, Oakhill i Lemmon, 2004; Kolić-Vehovec, 1994; Pečjak, KolićVehovec, Ajdišek, Rončević, 2009; Seigneuric, Ehrlich, Oakhill i Yuill, 2001 u Kolić-Vehovec (2013). 
teksta potrebno je određeno znanje o području $)^{8}$

c) Vrijednost teme-interes za temu (razumijevanje pročitanog u poveznici je s vrijednošću i zanimljivošću teme i zadatka) (usp. Kolić-Vehovec, Pejčak, Rončević Zubković 2009: 235)

d) Povezanost sa stvarnim životom - sadržaji bliski, korisni i potrebni učenicima (uočavanje važnosti primjenjivanja strategija za učenje u svim predmetima).

Tekstovi mogu biti didaktički priređeni ${ }^{9}$ (pronalazimo ih u udžbenicima za Hrvatski jezik, ali i za druge nastavne predmete), te didaktički nepriređeni u znanstveno-stručnoj literaturi i tiskovinama. Nepriređene tekstove učitelj može prilagoditi, uz napomenu o vlastitim preinakama unutar teksta. Tekstovi moraju biti cjeloviti i ne predugi kako ne bismo narušili obavijesnu poruku teksta. Isto tako, duljinu teksta valja prilagoditi spoznajnim mogućnostima učenika i postupno, sukladno dobi i uvježbanosti, produljivati.

\section{METODIČKI MODEL NASTAVNOGA SATA - „ČOKOLADA U KNJIŽEVNIM I NEKNJIŽEVNIM TEKSTOVIMA“}

Nastavna tema nastavnog područja jezično izražavanje u 5. razredu, prema Nastavnom planu i programu za osnovnu školu, jest slušanje književnih $i$ neknjiževnih tekstova (ključni pojmovi: književni i neknjiževni tekst; obrazovna postignuća: razlikovati književne i neknjiževne tekstove na temelju slušnog primanja). U obradbi ove teme, kad je neknjiževni tekst nastavni sadržaj (uočavanje funkcionalnostilističkih obilježja neknjiževnog teksta u odnosu na književni tekst), on je nezaobilazno i nastavni izvor, pa je to dobra prilika za uočavanje obavijesnih obilježja teksta, te uvježbavanje strategije sažimanja. Metodički je model provjeren u nastavnoj praksi te su upravo poteškoće učenika sa sažimanjem i izdvajanjem ključnih riječi i oblikovanjem sažetka na temelju ključnih riječi u fazi samostalnog uvježbavanja potaknule pisanje ovog rada.

Korišteni neknjiževni tekstovi:

$\checkmark$ Plakat - reklama za Riječku tvornicu čokolade

$\checkmark$ Đekić, V., Riječka tvornica kakaa i čokolade. Portal Moja Rijeka, 2012. (novinski članak)

8 Kolić-Vehovec (2013).

9 Usp. Nemeth-Jajić, J. (2013). 
$\checkmark$ Car, H., Čokolada - za slađi početak školske godine, Matka 22, br. 85 (kratko priopćenje)

$\checkmark$ Hrskavi čokoladni mozaik, recept

Korišteni književni tekstovi:

$\checkmark$ Dahl, R., Čarli i tvornica čokolade (ulomak)

Predviđeno vrijeme obradbe: školski dvosat (2 x 45 minuta)

Tip sata: uvježbavanje

Oblik rada: frontalni/individualni rad i rad u skupinama

Prvi nastavni sat - motiviranje i modeliranje

\section{a) Motiviranje učenika za recepciju neknjiževnog teksta}

U uvodnome dijelu sata učenike valja motivirati za recepciju neknjiževnog teksta i temu nastavnog sata. Motivacija se temelji na čitanju plakata za Riječku tvornicu čokolade. Plakat prvo prikazujemo pokrivajući verbalne informacije kako bismo pobudili učeničku maštu te oni, na temelju vizualne predodžbe, iznose asocijacije o reklamiranom proizvodu, a potom se i pomoću verbalnih informacija i leksičkom vježbom (elefant - cacao - csokolade - fiume) uspostavlja spoznajni kontekst.

\section{b) Središnji dio sata-modeliranje}

U središnjem dijelu sata učitelj naglas čita didaktički prilagođen članak Velida Đekića, Riječka tvornica kakaa i čokolade. Kako bi i učenici bili uključeni u prvu fazu poučavanja strategije sažimanja - fazu modeliranja, dobivaju zadatak da tijekom slušanja neknjiževnog teksta zapisuju ključne informacije (datume, mjesta, nazive). Nakon što učitelj pročita tekst, upoznaje učenike sa strategijom sažimanja i njezinom važnošću za učenje u svim nastavnim predmetima. Uz pomoć učeničkih zapisa, izdvaja ključne informacije, komentira učeničke zapise i po potrebi ih dopunjava i oblikuje nekoliko vlastitih formulacija temeljenih na autorovim idejama, pazeći da pritom slijedi strukturu i redoslijed originalnog teksta. Učitelj se pritom služi metodom razmišljanja naglas, verbalizirajući svaku fazu oblikovanja sažetka (izdvajanje ključnih pojmova - povezivanje s glavnim idejama autora - oblikovanje vlastitih formulacija).

Potom učenici slušaju čitanje književnog teksta, ulomak iz romana R. Dahla, Čarli i tvornica čokolade, te uočavaju, ponavljaju i uspoređuju obilježja 
književnog i neknjiževnog teksta, a ako za to imamo vremena, možemo sažeti i književni tekst prema prijedlozima K. Visinko (2014: 109-110).

\section{c) Završni dio sata}

Učenici dobivaju uputu o samostalnom čitanju kratkih ulomaka neknjiževnog teksta H. Car, Čokolada - za slađi početak školske godine (ulomci nisu duži od 10 rečenica) koji će biti predložak za uvježbavanje sažetaka na drugom nastavnom satu.

Drugi nastavi sat - promatranje izvođenja zadatka i samostalno uvježbavanje

\section{a) Uvodni dio sata}

Učitelj, nakon što su učenici prvi put pročitali ulomke, daje uputu o ponovnom čitanju uz izdvajanje jedne zanimljivosti u ulomku te triju ključnih riječi koje predstavljaju bit teksta. Tijekom ove faze nastavnog sata učitelj postupno prebacuje odgovornost na učenike, promatra izvođenje zadatka, obilazi, daje povratnu informaciju, sugerira i podupire učenike.

\section{b) Središnji dio sata - promatranje izvođenja zadatka}

Središnji dio sata temelji se na radu u manjim skupinama kad učenici, koji su čitali iste ulomke, komentiraju izdvojene ključne riječi i zajednički komentiraju uspješnost odabira pojedinih ključnih riječi u odnosu na bit teksta. Potom, po ključnim riječima oblikuju sažetak i predstavljaju ga cijelom razrednom odjelu. Radom u skupinama učenici će moći vrednovati svoj rad i napredak u odnosu na druge učenike, a potom će ih vrednovati i učitelj kao skupinu. Vrednovanje vlastitog napretka neizostavan je motivacijski čimbenik u poučavanju strategijama čitanja jer, ako učenici sami procjenjuju svoj napredak, veća je vjerojatnost da će svoj uspjeh pripisati ulaganju napora, što će povećati motivaciju (Rončević Zubković 2013: 36) .

\section{c) Završni dio sata}

U završnom dijelu sata važno je ponoviti naučeno i uputiti učenike na samostalno uvježbavanje strategije sažimanja. Kao zadatak za domaću zadaću 
učenici mogu sažimati samostalno odabrani ulomak didaktički pripremljenog udžbeničkog teksta najdražeg predmeta $\mathrm{s}$ ciljem uvježbavanja strategije sažimanja ili po neknjiževnom tekstu - receptu za Hrskavi čokoladni mozaik - oblikovati književni tekst (uključivanjem stilskih izražajnih sredstava, pripovjednih tehnika, likova, subjektivnosti).

\section{ZAKLJUČAK}

Književni se tekst razlikuje od neknjiževnog teksta prema načinu čitanja i osobinama samog teksta, koje upozoravaju da se književno djelo jezikom služi na osobit način. Neknjiževni tekstovi u nastavi Hrvatskog jezika obuhvaćaju tekstove različitih funkcionalnih stilova: znanstvenog, novinarskog, administrativnog, razgovornog, ali i tekstove sekundarnih funkcionalnih stilova: esejističkog, scenarističkog, reklamnog, stripovnog i retoričkog te epistolarnog i sakralnog stila. Iako je obrazovna politika i zakonska regulativa prepoznala važnost neknjiževnih tekstova za nastavu materinskog jezika i ostvarivanje cjelokupnosti jezične i komunikacijske prakse, nastavna se praksa i dalje uglavnom temelji na tekstovima književnoumjetničkog stila u svim nastavnim područjima Hrvatskog jezika, dok su tekstovi drugih funkcionalnih stilova rjeđe zastupljeni.

Potrebu za poučavanjem i uvježbavanjem strategija čitanja, s posebnim naglaskom u ovom radu na jednu od najučinkovitijih strategija, strategiju sažimanja, vidimo $\mathrm{u}$ njihovoj pozitivnoj povezanosti $\mathrm{s}$ razumijevanjem pri čitanju i svekolikim učenjem u svim nastavnim predmetima i cjeloživotnom učenju. Učenici često na nastavnim satima uvježbavaju prepričavanje na primjerima književnih tekstova, lektirnih naslova, filmova, događaja, te uvježbavanjem postaju sve uspješniji u tom obliku jezičnog izražavanja. Međutim, prepričavanje se unekoliko razlikuje od sažimanja jer se sažimanje temelji na skraćivanju originalnog teksta koje obuhvaća glavne autorove ideje, uključuje važne informacije koje podupiru te ideje te reflektira strukturu i redoslijed originalnog teksta, a prepričavanje je usmeno iskazivanje upamćenog iz slušanog ili čitanog teksta. Sažimanje se u nastavnoj praksi dijelom ostvaruje određivanjem kompozicijskih dijelova epskih i dramskih tekstova, ali nam uvid u nastavnu praksu pokazuje kako učenici imaju poteškoća sa sažimanjem upravo neknjiževnih tekstova, posebice u izdvajanju ključnih informacija i oblikovanju sažetka kao najsloženijeg oblika jezičnog izražavanja. Teško razlučuju bitno od nebitnog, što utječe na uspješnost učenja. Razlog tome vidimo u neuvježbanosti i površnom poznavanju pojedinih strategija učenja i čitanja, čemu mi učitelji 
možemo znatno doprinijeti. Za uspješno samostalno korištenje strategije sažimanja potrebno je višekratno modeliranje i uvježbavanje na različitim vrstama tekstova. Prikazani metodički model nastavnog sata prema modelu postupnog prenošenja odgovornosti može poslužiti kao motivacija i smjernica učiteljima kako u različitim nastavnim temama, sadržajima i tipovima nastavnih sati uvježbavati ovu, ali i druge strategije, za uspješnije ostvarivanje školskih i profesionalnih postignuća naših učenika.

\section{LITERATURA}

Car, H. (2013). "Čokolada - za slađi početak školske godine“. Pristupljeno: 10. 6. 2015. URL: <http://hrcak.srce.hr/125718?lang=hr>.

Čudina-Obradović, M. (2014). Psihologija čitanja - od motivacije do razumijevanja. Zagreb: Golden marketing.

Dahl, R. (2011). Charlie i tvornica čokolade. Zagreb: Znanje.

Đekić, V. (2012). "Riječka tvornica kakaa i čokolade“. Pristupljeno: 10. 6. 2015. URL: $\quad<$ http://www.mojarijeka.hr/kolumne/rijecka-tvornica-kakaa-icokolade/>. "Hrskavi čokoladni mozaik". Pristupljeno: 10. 6. 2015. URL: $<$ https://www.profil-klett.hr/datoteke/cokoladaza_razredna_n.pdf.>

Katnić-Bakaršić, M. (1999). "Lingvistička stilistika". Pristupljeno: 28. 5. 2016. URL: $<$ http://rss.archives.ceu.hu/archive/00001017/01/18.pdf>

Kissner, E. (2006). "Summarizing, paraphrasing, and retelling: skills for better reading, writing, and test taking“. Pristupljeno: 17. 10. 2015. URL: $<$ https:// www.heinemann.com/shared/onlineresources/E00797/chapter2.pdf>.

Kolić-Vehovec, S., Pečjak, S., Rončević Zubković, B. (2009). "Spolne razlike u (meta) kognitivnim i motivacijskim čimbenicima razumijevanja teksta adolescenata u Hrvatskoj i Sloveniji“. Suvremena psihologija 12: 229-242. Kolić-Vehovec, S. (2013). "Kognitivni i metakognitivni aspekti čitanja“, u Čitanje za školu $i$ život, ur. M. Mićanović (Zagreb: Agencija za odgoj i obrazovanje): 23-32.

Lešić, Z. (2012). Teorija književnosti. Pristupljeno: 29. 5. 2016. URL: https:// www.scribd.com/doc/97816612/Teorija-knji\%C5\%BEevnosti-Zdenko$\mathrm{Le} \% \mathrm{C} 5 \% \mathrm{~A} 1 \mathrm{i} \% \mathrm{C} 4 \% 87$

Ministarstvo znanosti, obrazovanja i športa. (2006). Nastavni plan i program za osnovne škole. Zagreb.

Ministarstvo znanosti, obrazovanja i športa. (2010). Nacionalni okvirni kurikulum za predškolski odgoj i obrazovanje te opće obvezno i srednjoškolsko obrazovanje. Zagreb. 
"Nacionalni kurikulum nastavnog predmeta Hrvatski jezik - prijedlog" (2016). Pristupljeno: 20. 3. 2016. URL: <http://www.kurikulum.hr/wp-content/ uploads/2016/03/Hrvatski-jezik.pdf $>$.

Nemeth-Jajić, J. (2013). "Metodički aspekti čitanja neknjiževnih tekstova u nastavi hrvatskoga jezika“, u Čitanje za školu i život, ur. M. Mićanović (Zagreb: Agencija za odgoj i obrazovanje): 105-115.

Pečjak, S., Kolić-Vehovec, Rončević Zubković, B., Ajdišek, N. (2009). “(Meta) kognitivni i motivacijski prediktori razumijevanja teksta adolescenata $\mathrm{u}$ Hrvatskoj i Sloveniji“. Suvremena psihologija 12/2: 257-270.

Plakat za riječku tvornicu čokolade. Pristupljeno: 10. 6. 2015. URL: $<$ https:// www.google.hr/search?q=rije \%C4\%8Dka+tvornica $+\% \mathrm{C} 4 \% 8$ Dokolade\& biw $=1366 \&$ bih $=643 \&$ source $=1 \mathrm{nms} \&$ tbm $=i$ sch $\&$ sa $=$ X\&ved $=0$ ahUKEwiB h5fPoe7LAhXECSwKHbUsA_cQ_AUIBigB\#imgdii=5MhYaKgOR9VS eM\%3A\%3B5MhYaKgOR9VSeM\%3A\%3BBOJEL0hO0D7ZvM\%3A\&i mgrc $=5 \mathrm{MhYaKgOR} 9 \mathrm{VSeM} \% 3 \mathrm{~A}>$.

Rončević Zubković, B. (2013). "Samoregulacija čitanja", u Čitanje za školu $i$ život, ur. M. Mićanović (Zagreb: Agencija za odgoj i obrazovanje): 33-41.

Solar, M. (1996). Teorija književnosti. Zagreb: Školska knjiga.

Težak, S. (1996). Teorija i praksa nastave hrvatskoga jezika. Zagreb: Školska knjiga.

Udier, S. L. (2011). “Jezik književnosti u modernome hrvatskome jezikoslovlju i književnoj znanosti“". Pristupljeno: 29. 5. 2016.

URL:http://www.matica.hr/kolo/318/Jezik\%20knji\%C5\%BEevnosti\%20 u $\% 20$ modernome $\% 20$ hrvatskome $\% 20$ jezikoslovlju $\% 20$ i\% 20 knji\%C5\%BEevnoj\%20znanosti/.

Visinko, K. (2003) "Neknjiževna lektira u osnovnoj školi“. Hrčak 17: 20-24.

Visinko, K. (2010). Jezično izražavanje u nastavi hrvatskoga jezika. Pisanje. Zagreb: Školska knjiga.

Visinko, K. (2014). Čitanje - poučavanje i učenje. Zagreb: Školska knjiga.

Jasna Bićanić

University of Zagreb

Faculty of Philosophy, Zagreb - postgraduate studies of glotodidactics

Zagreb

University of Rijeka

Faculty of Philosophy, Rijeka (visiting professor)

Rijeka

jasna.bicanic@uniri.hr 


\section{NON-LITERARY TEXTS IN TEACHING THE STRATEGY OF SUMMARIZING}

\section{Summary}

A literary text differs from a non-literary one based on the reading mode, and the characteristics of the text itself. This points to the fact that a literary text uses a language in a specific way. Non-literary texts in Croatian language teaching include texts with various functional styles, i.e. scientific, journalistic, administrative, and conversational, but also texts with secondary functional styles, i.e. essayist, scenarist, commercial, comic book - style, rhetorical, as well as epistolary and sacral style. The educational policy and legislation have acknowledged the importance of non-literary texts in mother tongue teaching, as well as their contribution to the overall linguistic and communicational practice. However, the Croatian language teaching methods are mostly based on the belletristic style, while texts with other functional styles are underrepresented.

The need to teach and practice reading strategies is evident in their positive connection to reading comprehension, and an overall positive effect in learning. The benefits are also evident in other classes, as well as in lifelong learning. This paper deals specifically with summarizing as one of the most efficient reading strategies.

However, students often practice retelling literary texts, required readings, movies, and events and that leads to successful mastering of this type of language expression. Nevertheless, retelling differs from summarizing. Namely, summarizing is based on shortening the original text so that it grasps the main ideas produced by the author, includes important information that support those ideas, and reflects the structure as well as the order of the original text. On the other hand, retelling is an oral demonstration of memorized chunks of heard or read text. In teaching practice, summarizing is done by identifying compositional parts of epic and drama texts. However, an insight into those teaching practices shows that students encounter challenges with summarizing non-literary texts, especially when it comes to identifying key information, and writing summaries as most difficult modes of language expression. Moreover, students manifest difficulties in distinguishing what is important from what is not, which affects their learning process. This is caused by the lack of practice and superficial knowledge of learning and reading strategies. On the other hand, it is also an area of great potential for teacher's contribution.

A methodological model of a teaching class, based on the Gradual Release of Responsibility Model, has been presented in this paper as an example for motivating teachers and creating guidelines for developing practices. These practices would ensure introducing the strategy of summarizing through various teaching topics, content, and classes, with a goal of contributing to the academic and professional success of our students.

Key words: non-literary text, reading strategies, summarizing, Croatian language, Gradual Release of Responsibility Model.

Primljeno: 1. 4. 2016.

Prihvaćeno: 6. 6. 2016. 